\title{
PRODUÇÃO E DIFUSÃO DO CONHECIMENTO CIENTÍFICO DA ENFERMAGEM NA ATUALIDADE: DESAFIOS E IMPLICAÇÕES NA FORMAÇÃO E QUALIFICAÇÃO DO ENFERMEIRO
}

Neide Aparecida Titonelli Alvim ${ }^{1}$

Para se discutir a produção e difusão do conhecimento de uma determinada área, tornam-se importantes e indispensáveis a sua articulação à pesquisa e o seu financiamento pelas agências nacionais de fomento encarregadas da política de desenvolvimento da pós-graduação e da ciência e tecnologia, tendo em vista as áreas e estratégias prioritárias. Nessa lógica, a definição das prioridades de investimento em pesquisa se articula com a visão governamental sobre a ciência, a pesquisa e a tecnologia.

Denota-se daí que a produção do conhecimento deve ter como uma de suas premissas atender às demandas da sociedade, considerando seus nexos entre as políticas públicas e o desenvolvimento socioeconômico do país. Isto implica uma estreita relação entre o sistema educacional e as exigências da ciência e da tecnologia, permitindo, sobretudo, alimentar as expectativas de construção de uma sociedade includente e mais justa. No que tange ao desenvolvimento profissional, a construção de conhecimentos sólidos capazes de produzir avanços significativos na prática é condição essencial para garantir a credibilidade de uma profissão.

A implantação dos cursos de mestrado e, posteriormente, de doutorado em Enfermagem trouxe grandes benefícios e se constituiu em uma importante estratégia para o for talecimento da profissão no campo da ciência. A pesquisa começou a se estruturar, surgiram as subáreas do conhecimento e estabeleceram-se políticas próprias da área. Os movimentos de formação de redes, com a organização dos grupos e linhas de pesquisa, vêm favorecendo o aprofundamento dos conhecimentos de enfermagem, principalmente a partir do desenvolvimento dos grupos de pesquisa (GP). Atualmente, 0 Diretório de GP do CNPq registra 328 GPs na área. A implantação do comitê próprio da área da Enfermagem, no CNPq, também se apresenta na relação de espaços conquistados pela profissão no âmbito da comunidade científica de modo a conferir-lhe maior visibilidade às especificidades de sua produção.

No que concerne à difusão do conhecimento produzido, a criação dos periódicos específicos de Enfermagem, com destaque para a Revista Brasileira de Enfermagem (REBEn), a primeira a ser criada, e o Centro de Pesquisa em Enfermagem (CEPEn), ambos vinculados à Associação Brasileira de Enfermagem (ABEn), impulsionaram a divulgação científica da área. Outra iniciativa da ABEn neste mesmo pleito é a promoção bienal do Seminário Nacional de Pesquisa em Enfermagem.

No bojo dos desafios que se colocam à produção e difusão do conhecimento na Enfermagem está o investimento na formação do jovem cientista, da graduação à formação do doutor. Sobre a validação da pesquisa produzida, há de se ressaltar que, além da importância de sua aplicabilidade na prática, esta se apresenta diretamente ligada à sua difusão na sociedade científica, sendo um dos indicadores que permitem avaliar o crescimento científico e tecnológico de uma determinada área, já que é principalmente pela difusão que se ampliam as discussões e reflexões que retroalimentam a produção.

No âmbito da formação profissional, é preciso trabalhar no entendimento fecundo do compromisso social da profissão com a qualidade de vida e de saúde das pessoas, articulando na formação do enfermeiro a pesquisa com a extensão, esta entendida como laboratório vivo para o desenvolvimento de investigações e de vivência acadêmica nas relações estabelecidas no âmbito do processo de ensino-aprendizagem. É preciso proporcionar possibilidades de experiências de integração social de modo que o estudante e o professor possam se atualizar diante das demandas da realidade e dos problemas sociais, e das repercussões destes na vida acadêmica e no processo ensino-aprendizagem.

Quanto à pós-graduação, é necessário manter ativos o espírito solidário e a cooperação internacional. Hoje, um dos maiores desafios em termos da ciência, da tecnologia e da educação de pós-graduação é o combate às desigualdades regionais. Torna-se imperativo que a Enfermagem, como profissão, desenvolva um corpo relevante de conhecimentos e habilidades para garantir sua existência como ciência e atender às mudanças necessárias no plano social, reconhecendo a complexidade humana no desenvolvimento de sua base teórica e a limitação do pensamento linear e da visão fragmentada para tratar problemas complexos. 


\section{PRODUCTION AND DISSEMINATION OF NURSING SCIENTIFIC KNOWLEDGE TODAY: CHALLENGES AND IMPLICATIONS FOR EDUCATION AND QUALIFICATION OF NURSES}

Neide Aparecida Titonelli Alvim ${ }^{1}$

When discussing the production and dissemination of knowledge in a particular area, it is important and necessary to tie it to the research and the funding of this research by the national sponsorship agencies responsible for policy development and postgraduate science and technology, without losing sight of the priority areas and strategies. Under this logic, the definition of priorities for investment of resources for research is related to the Government's view on science, research and technology.

Hence one of the major premises of knowledge production must be to meet the demands of society, given its link with public policy and socioeconomic development. This implies the existence of a close relationship between the education system and the demands of science and technology, which fuels expectations of building a more just and inclusive society. With regards to the professional development, building a solid knowledge capable of producing significant advances in practice is essential to ensure the credibility of a profession.

The implementation of master degrees, and later, doctorate degrees, in the nursing area has brought significant benefits and has become an important strategy for strengthening the profession in this field of science. The investigation started to get structured, sub-areas of knowledge emerged and policies were established for this field of knowledge. The movements of networking - with the organization of groups and lines of research - have helped to strengthen and deepen knowledge of nursing, particularly through the development of Research Groups (GP, acronym in Portuguese).

Currently, the Board of GP National Council for Scientific and Technological Development (CNPq, Portuguese acronym) has 328 research groups registered for this area. The insertion of a special committee of nursing at CNPq is part of the relationship of space conquered by the profession in the scientific community field in order to give greater visibility to the specificities of their production.

Regarding the dissemination of the knowledge produced, the creation of specific nursing journals, especially the Brazilian Journal of Nursing (Reben), the first created, as well as the Center for Nursing Research (CEPEn), both linked to the Brazilian Association of Nursing (ABEN), actively supported the scientific dissemination of this area. Another initiative is ABEn's promotion of a biennial National Seminar on Nursing Research.

Amid the challenges faced in relation with the production and dissemination of knowledge in nursing, is the investment of resources in the formation of young scientists - from graduation to doctorate. In addressing the validation of the research produced, it is necessary to emphasize that besides the importance of being applied in practice, it appears directly related to the dissemination in the scientific community, as an indicator to assess the growth of science and technology in a given area, since it is spread mainly by greatly expanding the discussions and reflections that provide feedback to the production.

In the field of professional education, it becomes s necessary to work the fer tile understanding of the social commitment of the profession with the quality of life and health of people, linking, within the nurse's education, research with extension, considered as a living laboratory for the development of research and academic experience in the relations established in the field of teaching and learning process. It is also necessary to provide opportunities for social integration experiences for the student and the teacher so they remain updated for the demands of reality, social problems and the way how they impact academic life and the teaching-learning process.

In relation to graduate education, it is indispensable to keep the spirit of solidarity and international cooperation alive. Today, one of the greatest challenges in terms of science, technology and graduate education, is to combat regional disparities. It is imperative that the nursing profession develops a relevant body of knowledge and skills to ensure its existence as a science and meet the necessary changes in the social field, recognizing the human complexity in the development of the theoretical basis and the limitations of linear thinking and of fragmented vision to address complex problems. 


\section{PRODUCCIÓN Y DIFUSIÓN DEL CONOCIMIENTO CIENTÍFICO DE LA ENFERMERÍA EN LA ACTUALIDAD: RETOS Y CONSECUENCIAS PARA LA FORMACIÓN Y CALIFICACIÓN DEL PERSONAL DE ENFERMERÍA}

Neide Aparecida Titonelli Alvim ${ }^{1}$

Para discutir la producción y difusión de un determinado ámbito del conocimiento, es importante e indispensable vincularla a la investigación y al financiamiento realizado por organismos nacionales de promoción encargados de las políticas de desarrollo de los programas de posgrado, ciencia y tecnología, sin perder de vista las áreas y estrategias prioritarias. Bajo esta lógica, la delimitación de prioridades para la inversión de recursos destinados a la investigación está relacionada con la visión gubernamental sobre la ciencia, la investigación y la tecnología.

De ahí que una de las premisas principales de la producción del conocimiento debe ser satisfacer las demandas de la sociedad, dado su vínculo con la política pública y el desarrollo socioeconómico del país. Esto implica la existencia de una relación estrecha entre el sistema educativo y las exigencias de la ciencia y la tecnología, lo que permite, especialmente, alimentar las expectativas de construir una sociedad inclusiva y más justa. En lo que al desarrollo profesional se refiere, la construcción de un conocimiento sólido capaz de producir avances significativos en la práctica es esencial para garantizar la credibilidad de una profesión.

La implantación de cursos de maestría y, posteriormente, de doctorado, en el área de enfermería, ha aportado grandes beneficios y se ha convertido en una estrategia importante para el fortalecimiento de la profesión en el ámbito de la ciencia. La investigación empezó a estructurarse, surgieron subáreas del conocimiento y se establecieron políticas para este campo. Los movimientos de creación de redes, con la organización de grupos y líneas de investigación, han ayudado a fortalecer y profundizar los conocimientos de la enfermería, principalmente a través del desarrollo de grupos de investigación (GP, sigla en portugués).

Actualmente, el Directorio de GP del Consejo Nacional de Desarrollo Científico y Tecnológico (CNPq, sigla en portugués) tiene registrado 328 grupos de investigación para esta área. La inserción de un comité específico del área de enfermería en el CNPq forma parte de la relación de los espacios conquistados por esta profesión en el ámbito de la comunidad científica con el fin de dar mayor visibilidad a las especificidades de su producción.

En lo que a la difusión del conocimiento producido se refiere, la creación de revistas de enfermería específicas destacando especialmente la Revista Brasileña de Enfermería (REBEn, sigla en portugués) primera revista creada - así como el Centro de Estudios e Investigación para la Enfermería (CEPEn, sigla en portugués), ambos vinculados a la Asociación Brasileña de Enfermería (ABEN, sigla en portugués) promovieron la difusión científica de esta área. Otra iniciativa de la ABEN es promover, bianualmente, el Seminario Nacional de la Investigación en Enfermería.

En medio de los desafíos que enfrentan la producción y difusión de los conocimientos en enfermería está la inversión de recursos en la formación de jóvenes científicos - desde la formación hasta el doctorado. Al abordar la validación de la investigación realizada es necesario resaltar, que además de la importancia que tiene ser aplicada en la práctica, es necesario que se produzca relacionada directamente con su difusión en la sociedad científica, como un indicador que permita evaluar el crecimiento científico y tecnológico de una determinada área, ya que es a través, principalmente, de la difusión, que se amplían los debates y reflexiones que retroalimentan esta producción.

En el ámbito de la formación profesional, es necesario trabajar la comprensión fértil del compromiso social de la profesión con la calidad de vida y la salud de las personas, vinculando, dentro de la formación del profesional de enfermería, la investigación con la extensión, considerado como un laboratorio viviente para el desarrollo de la investigación y la experiencia académica en las relaciones establecidas en el ámbito del proceso de enseñanza y aprendizaje. Es necesario ofrecer oportunidades de experiencias de integración social para que el estudiante y el profesor puedan mantenerse actualizados frente a las exigencias de la realidad, a los problemas sociales y a la forma en cómo estos repercuten en la vida académica y en el proceso enseñanza-aprendizaje.

En lo referente al posgrado, es necesario mantener vivo el espíritu solidario y la cooperación internacional. Hoy en día, uno de los mayores desafíos, en términos de la ciencia, la tecnología y la educación de posgrado, es la lucha contra las desigualdades regionales. Es imperativo que la enfermería como profesión desarrolle un cuerpo relevante de conocimientos y habilidades para garantizar su existencia como ciencia y cumplir con los cambios necesarios en el ámbito social, reconociendo la complejidad humana en el desarrollo de sus bases teóricas, en las limitaciones del pensamiento lineal y en la visión fragmentada para enfrentar problemas complejos. 